\title{
From Specific to General in Electoral Cycle Models
}

\section{Do Específico ao Geral nos Modelos do Ciclo Eleitoral}

\author{
António Bento Caleiro, University of Évora
}

\begin{abstract}
The article considers a way of generalizing the, so-called, stylized, which is also a specific model of electoral cycles. This generalization consists on assuming that the output level does indeed exhibit persistence, i.e. its current value (may be) being a function (also) of its past value. In an integrated way, the consequences of this generalization are analyzed.

Keywords-Electoral Cycles, Output Persistence.

Resumo-Neste trabalho considera-se uma forma de generalizar o modelo, dito estilizado, o qual é também específico, de ciclos eleitorais. Esta generalização consiste em admitir que o produto, de facto, exibe persistência, i.e. o valor corrente (poder) ser função (também) do seu valor passado. De uma forma integrada, analisam-se as consequências daquela generalização.
\end{abstract}

Palavras-Chave-Ciclos Eleitorais, Persistência de Output.

Submitted-27-05-2018. Accepted-03-12-2018.

"As I would not be a slave, so I would not be a master. This expresses my idea of democracy."

\section{Abraham Lincoln}

\section{Introduction ${ }^{1}$}

$\mathrm{M}$ OST of the early theories about the behavior of Government assumed, more or less explicitly, that this agent would determine,

- António Bento Caleiro,Professor at the Department of Economy, University of Évora, Portugal.

E-mail: Caleiro@uevora.pt

ORCID: https://orcid.org/0000-0003-1205-4404

DOI:http://dx.doi.org/10.21814/perspectivas.137

1. This article consists (in a brief update) of the essential part of the seminar - option legally covered by section c, article 5, of the Decree-Law no. 239/2007 of June 19 - presented during our 'provas de agregação' in Economics. In order to clearly assume a multiple perspective on the question, which should have been evident, this justified the bibliographical references that were used, which we did not want to eliminate in this article, given our willingness to remain as close as possible to the original. and subsequently enforce, decisions that would be optimal according to a social welfare function. ${ }^{2}$ The delegation of decision power in this agent by the society should, as a rule, be ensured through (democratic) elections.

Thus, according to that view of the Government, voters, through an electoral process, would choose an agent who was supposed to take decisions, namely economic policies, which would be the best from the society viewpoint. ${ }^{3}$ In fact, these decisions would be better for voters, in particular, and for society, as a whole, than those

2. In fact, this view of the Government as a "benevolent dictator" continues to be highly regarded, albeit for example under the name of "social planner", either in macroeconomics (Sargent 1987; and/or Ljungqvist and Sargent 2004), or in microeconomics (Mankiw 2008). For example, for Mankiw (2008, 147), "The benevolent social planner is an all-knowing, all-powerful, well-intentioned dictator. The planner wants to maximize the economic well-being of everyone in society.".

3. In a sense, it is being assumed that voters represent the society. 
that would be taken by voters (or society) if voters (or society) had decision-making power. This traditional view resulted from the consideration that the Government would consider the consequences of its decisions over a longer time horizon, more correctly time-discounted, than that considered by the electorate itself.

Authors associated with the public choice school were the first to stand out in challenging that view of the Government being a "benevolent dictator". According to these authors, the Government, like any other economic agent, should be considered as a selfish agent in its decisions, i.e. an agent pursuing its own interests, which in some circumstances might not coincide with the maximization of social welfare. Thus, the Government could be seen as an agent made up of politicians, whose desire to be re-elected, i.e. their private interest, might not be compatible with social welfare, i.e. with the general interest of society. ${ }^{4}$

Indeed, the basis for this alternative view is that the Government has two characteristics: it is an economic agent because it is one of the main actors in economic policy, and it is also a political agent, since it exists as a result of an electoral process in democracies. Thus, governmental action influences the state of the economy, but, in turn, the Government is also influenced by the economic situation, since the electorate usually considers it to be one of the main responsible for the state of the economy and, for this reason, rewards or

4. Being true that the economic analysis of political phenomena renders Black (1948, 1958), Arrow (1951), Downs (1957), Buchanan and Tullock (1962), and/or Olson (1965) of undeniable interest, their object of study does not correspond exactly to that considered in the models of electoral cycles. penalizes its performance at the polls. ${ }^{5}$

Regardless of the validity of the abovementioned arguments, the fact is that the existence of democratic elections is often associated with the issue of an electoral cycle created by the governments resulting from these same elections. Reality shows that governments always claim that its economic policy has no electoral purpose, while the opposition parties generally have a different view. Clearly, behind this exchange of accusations is the assumption that electoral cycles are an undesirable or unacceptable phenomenon. ${ }^{6}$

The social perception that an electoral cycle is an undesirable phenomenon anticipates a possible way to combat it. In the purely theoretical field, a naive approach would consider the imposition of a mandate of infinite duration as the only way to transform a selfish/opportunistic, i.e. electorally motivated Government, in an altruistic/benevolent Government, optimizing a social welfare function. Notwithstanding all the rest, this trivial solution can be called into question even in strictly economic terms.

Even if non-economic aspects are ignored, that is to say, if we disregard all the valid objectives inherent in the democratic process, namely freedom and/or peace (Caleiro 2017), the consideration of an entirely economic objective function still does not lead to an obvious answer to the question: is democracy bad for the economy? On the one hand, most electoral cycle theories share the conclusion that elections, in fact, may involve costs of an

5. This is the so-called responsibility or economic voting hypothesis (Lewis-Beck and Paldam 2000). As, according to this hypothesis, it is admitted that voters consider the Government to be responsible for the economic evolution, the voting or popularity functions, which explain the support to the Government as a function of its economic results, may easily become the objective functions for the economic policy of governments. Reflecting this approach, the first empirical studies on the subject began precisely with the formulation and (econometric) estimation of functions of this type. In fact, such empirical studies have been, and still are, so popular that hundreds of references can easily be counted. For example, Veiga and Veiga (2004) and Caleiro (2009a) are two examples of application to the Portuguese case. For a detailed survey on popularity or voting functions see Nannestad and Paldam (1994) and/or Lewis-Beck and Stegmaier (2013).

6. As stated in Caleiro (2018), a positive response to the question: "Should electoral cycles disappear?", is not (necessarily) desirable when politicians do not even care about the upcoming elections because a single - the current - mandate is sufficient to achieve their (ideological) intentions of (strictly) private/personal nature. 
economic nature. In general terms, this is because the instability created by electorally motivated governments is accepted as being detrimental to society in the long run. ${ }^{7}$ On the other hand, non ignoring the obvious non-economic benefits of democracy, there are at least four reasons why elections can also have economic benefits (Caleiro 2007a).

As is well known, elections allow to: $(i)$ take into account the preferences and interests of future generations; (ii) make a timely distinction between competent and incompetent governments; (iii) implement punitive or rewarding electoral strategies, in accordance with the economic performance of governments; (iv) determine the behavior to be assumed by the electorate so that the more a Government acts according to the genuine social interests, the more it is rewarded in the elections. By these means, elections have an economic importance that generalizes to democracy itself. ${ }^{8}$

That said, it is our aim to present an insight into the economic importance of elections by exploring (some of) possible developments on issues not yet sufficiently addressed (in an integrated way) in the literature on electoral cycles. ${ }^{9}$ Being of an integrated nature, this vision will result in

7. The inclusion of popularity in the objective function of the Government, which implies the existence of economic cycles as electorally induced cycles, is in contrast with the traditional explanations of the business cycle, which focused on the role of random 'shocks' and structural instability. In fact, the theory of stabilization was obviously based on the assumption that the government should stabilize the economy. The ability to actually do so was questioned by the monetarists in the late 1960s and 1970s, but the political-economic modeling has pointed out a reason to believe that governments are not only unwilling to stabilize the economy but that they intentionally create some cyclical instability, in order to obtain electoral gains.

8. In fact, there are various links between economic aspects and political aspects, whereby elections can play an economic role. For example, the relationships that exist between some economic aspects, namely growth, and some political aspects, namely the level of democracy, have been the subject of some theoretical and also empirical interest (Alesina and Perotti 1994; Alesina and Rodrik 1994; Alesina et al. 1996; Barro 1996; Persson and Tabellini 2006). In a sense related with those links, it is also possible to consider the electoral consequences of ageing (Caleiro 2007b, 2009b) and/or of unemployment (Caleiro 2016).

9. As is well known, the literature in this area is very extensive, and there are works that deal exclusively with the analysis of the interaction between economic and political spheres. Among others, see Alesina et al. (1997) and/or Persson and Tabellini (1990, 2003, 2003). Some interesting surveys of the literature can be found in Gärtner (1994a, 2000) and/or Persson and Tabellini (1999). a justified generalization of the particular/specific case that is usually considered in the literature, i.e. the so-called stylized model of electoral cycles (Caleiro 2000a). ${ }^{10}$

Thus, in section 2 we will present the model, which theoretically is based on an aggregate supply curve without persistence in the level of real economic activity [hypothesis $(a)$ ], and on a fixed duration of the mandate [hypothesis $(b)],{ }^{11}$ while, in terms of empirical verification, it has usually been the target of estimation by traditional econometric methods [practice $(a)] \cdot{ }^{12}$

A possible generalization of hypothesis (a) is to admit that the level of real economic activity may exhibit some persistence. ${ }^{13}$ Considering this fact, section 3 will analyze the consequences of persistence on the pattern of electoral cycles. These consequences are discussed in section 4, focusing on the use of the stylized model, i.e. of an (possibly) incorrect model, in case of output persistence. Section 5 presents the main limitations of this work, as a motivation for future research.

10. The designation 'electoral cycles' will be used for the general case, i.e. when the distinction between political and partisan cycles is not important. Following this terminology, a possible confusion between a particular case (i.e. the political case a la Nordhaus) and the general case is avoided. Still, there are authors that (unacceptably) make this confusion.

11. In this regard, it is important to draw attention to the fact that most of the theoretical literature has indeed considered models where the term of office is fixed, i.e. where the election date is exogenous. Some authors have considered, however, (theoretical) models in which the election date is of an endogenous nature, and it may be the government's objective to determine the optimal duration of the mandate (Balke 1990; Chappell and Peel 1979; Keppo et al. 2008; Lächler 1982), possibly depending on the date of the elections in a neighboring country (Caleiro 2010a). From another point of view, also the analysis of the consequences of the existence of early elections has been the subject of some studies (Balke 1991; Cargill and Hutchison 1991; Ellis 1991; Ellis and Thoma 1991; Heckelman 2002; Ito 1990; Kayser 2005; Smith 1996).

12. This practice is paradoxical when using regional data, where spatial econometric methods are, obviously, the most convenient ones (Agnew 1996; Beck et al. 2006; Franzese and Hays 2007; Kramer 1983; O'Loughlin 2003).

13. Being true that this concept will be duly formalized later, it is since now important to mention that persistence in a given variable occurs when there is an influence of the past value(s) on the current value of the variable. 


\section{The stylized model of electoral cy- cles}

As is well known, the literature on electoral cycles has developed into two distinct phases. The first, which took place in the mid-1970s, considered the existence of "naïve" voters, i.e. understood as nonrational (Nordhaus 1975; Hibbs 1977). Following the "revolution" of the rational expectations of the 1980s, the second generation of models considered (totally) rational voters (Alesina 1987; Persson and Tabellini 1990; Rogoff and Siebert 1988). ${ }^{14}$

Indeed, in a seminal paper in the mid-1970s, Nordhaus took a decisive step in the development of the theory of political (business) cycles. ${ }^{15} \mathrm{In}$ addition to assuming that the only objective of an opportunist government would be to maximize the number of votes in the subsequent election, Nordhaus (1975) also considered myopic and retrospective voters, i.e. an electorate that does not take into account the economic evolution beyond the (subsequent) elections.

As is well known, Nordhaus (1975) considered an optimal control, continuous time, model, based on a Phillips curve with adaptive expectations:

$$
\begin{aligned}
& \pi_{t}=f\left(u_{t}\right)+\lambda v_{t}, \\
& \dot{v}_{t}=\gamma\left(\pi_{t}-v_{t}\right),
\end{aligned}
$$

where $u$ represents the unemployment rate, and $\pi$ represents the inflation rate, whose expected value is $\nu$.

Thus, taking into account those restrictions, the Government's objective would be, during the mandate, lasting between $t=0$ and $t=T$, with voters having a memory rate, $\mu$, to maximize

$$
V=\int_{0}^{T} g(u, \pi) e^{\mu t} d t
$$

14. It is interesting to note that, in any of these generations of models, national space, even implicitly, constitutes the territory of interest. The analysis of the international or regional space can be found in Alesina and Tabellini (1987), Goyal and Staal (2004), Lohmann (1993), and Sapir and Sekkat (1999).

15. It is interesting to note that, according to Nordaus (1975, 181), although economists have so far made some casual observations about the political origins of the economic cycle, the only 'serious' theory would have been the of Kalecki (1943). where the instantaneous popularity function, $g(u, \pi)$, assumes a quadratic-linear format:

$$
g(u, \pi)=-u^{2}-\beta \pi, \quad \beta>0,
$$

being assumed that $\pi \geq 0 .{ }^{16}$

Behavioral assumptions, with respect to government and voters, lead to a typical political (business) cycle pattern, i.e. recessions at the beginning of each government's mandate and (inflationary) expansions at the end of the mandate. ${ }^{17}$ In fact, the same pattern of political (business) cycle can be obtained by using a stylized model, as is usually considered in the most recent literature.

The model consists of an aggregate supply curve:

$$
y_{t}=\bar{y}+\alpha\left(\pi_{t}-\pi_{t}^{e}\right)
$$

where $y_{t}$ represents the output level (in moment $t$ ), which presents deviations from its natural level, $\bar{y}$, whenever inflation $\pi_{t}$ (in moment $t$ ) does not coincide with its expected value, $\pi_{t}^{e}$ (Lucas 1973; Taylor 1980).

If the electorate votes according to the performance of the government, whose mandate is hypothetically divided into a non-electoral period, where $t=1 \equiv N$ and in an electoral period, where $t=1 \equiv \varepsilon$, taking into account the evolution of the output level, given by (1), and by inflation, according to the voting/popularity function:

$$
V=\mu V_{1}+V_{2}
$$

where $\mu \varepsilon] 0,1]$ is related to the memory rate of the electorate, and being the (quadratic-linear) function of instantaneous voting given by:

$$
V_{t}=-\frac{1}{2} \pi_{t}^{2}+\beta y_{t}
$$

it is straightforward to show that, in the case of adaptive expectations (for example, of the type

16. Note how the linearity of the state variable, $\pi$, in the popularity function forced Nordhaus (1975) to consider this assumption.

17. See figure 8 in Nordhaus $(1975,185)$. 
$\left.\pi_{t}^{e}=\pi_{t-1}\right)$, the optimal, from the electoral point of view, inflation rates, ${ }^{18}$ are such that:

$$
\pi_{2}\left(=\pi_{0}\right)>\pi_{1}
$$

These, in turn, result in:

$$
y_{1}<\bar{y}<y_{2}
$$

which confirms the typical political cycle pattern.

It is clear that, for the existence of depressions at the beginning of the mandate, followed by expansions at the end of the mandate, it is decisive that the economic performance of the government is weighted according to (2), that is, considering the future moments, i.e. those closest to the end of the mandate, more important than the present moments, i.e. those closest to the beginning of the mandate. This also means that an increase in the duration of the mandate, in this case (2) being replaced, for example, by:

$$
V=\mu_{1} V_{1}+\mu_{2} V_{2}+V_{3}
$$

in which $0<\mu_{1} \leq \mu_{2} \leq 1$, in no way does it change, in normal conditions, that pattern of political cycle. ${ }^{19}$

A critique of the political cycles a la Nordhaus was made by Hibbs (1977), who suggested the partisan approach in the literature of electoral cycles. The author considered a different form of ruling party action, as well as different behavior on the part of voters. In particular, Hibbs (1977) considered parties to be representatives

18. In the case $\pi_{t}^{e}=\pi_{t-1}$, it is easy to show that $\pi_{1}=\left(1-\frac{1}{\mu}\right) \alpha \beta$ and $\pi_{2}=\alpha \beta$.

19. In this kind of model, it is evident that, whatever the duration of the mandate, the inflation rate of the last moment of the mandate is given by $\alpha \beta$, while the other values of inflation reflect the memory rates associated with those other moments. Thus, for a sufficiently abnormal evolution of memory rates, it is indeed possible for inflation rates to decrease, and hence for this type of expectation, output being above its natural level, during part of the mandate. Indeed, even in the original formalization of Nordhaus (1975), the initial conditions for the expected inflation rate may result in an 'inverted' political cycle (Caleiro 2001). Also in the original version of Nordhaus (1975), the longer the term of office, the more pronounced the political cycle. This is not necessarily the case when considering a (fully) quadratic objective function (Caleiro 2010b). of different social classes, with different political preferences. In this context, it is admitted that the electorate vote in the party that best defends its political ideology, whereas electoral victories are not an end in themselves, but rather the means necessary to implement the best decisions for the political class that the party represents. ${ }^{20}$

Thus, taking a partisan approach, it is considered that political parties choose different points in their curve of possibilities in order to provide welfare gains to their fundamental (ideological) support bases. ${ }^{21}$ From this point of view, it is assumed that the right-wing parties on the political spectrum are more "averse" to inflation than the left-wing parties (in that spectrum). This hypothesis translates, in the stylized model, into the fact that the instantaneous objective function (3) is replaced by:

$$
V_{t}=-\frac{1}{2} \pi_{t}^{2}+\beta^{i} y_{t}
$$

with $i=R$ (rigth), $L$ (left), where $\beta^{R}<\beta^{L}{ }^{22}$

In this case, it is clear that during the term of office, the electoral cycle pattern (as above described) also occurs, regardless of the party in power, being sure that the optimal inflation rates will be the lower (resp. the higher) the more in the right (resp. left) on the political spectrum is the ruling party.

The empirical literature generated by the initial theoretical studies on the electoral cycles was not conclusive about its coherence with reality

20. It is interesting to note that this position of the electorate is not the subject of a great challenge, but in relation to the position assumed by the parties, they are the ones who, after being elected, seem to deny their ideological choice, claiming to be representatives of the entire electorate or of the entire population.

21. Minford and Peel (1982) and Minford (1990) considered an interesting alternative, i.e. one that we could classify as intermediate between the political (Nordhaus) and partisan (Hibbs) approaches. It is assumed that the parties are supported by their (ideological) bases and by some "floating" voters, who determine the outcome of the elections. In this case, maximizing a certain objective function leads to the best trade-off between the possibilities of winning the elections and ensuring the loyalty of their support bases.

22. It is important to note that (5), in fact, presents a qualitative difference with respect to (3), since it must be understood as an objective function of the party in government and not a voting function (of the entire electorate). 
(Alesina 1992; Alesina and Roubini 1992; Alesina et al. 1993; Gärtner 1994b; Gärtner 1999). ${ }^{23}$ Partly, as a reaction to these empirical studies, and partly as a response to the "revolution" of rational expectations, a new generation of models of (rational) electoral cycles emerged in the late 1980s.

These "second generation" models diverge from their predecessors in the behavior of the private sector in general and, in particular, of the electorate. The assumption of the rationality of voters reduces the possibility of regular electoral cycles, although it does not eliminate them completely, as will be shown below, using the stylized model that we have been using.

Considering that the expected inflation rate results from the application of rational expectations, i.e. $\pi_{t}^{e}=\mathrm{E}\left[\pi_{t} \mid \jmath_{t-1}\right]$, it is evident that the maximization of (2) subject to (1) results in:

$\pi_{t}=\alpha \beta$

regardless of the moment of the mandate.

Thus, in this version of the political cycle with rational expectations, the cycle does not exist at all, the economy being at its natural level at any time moment in the mandate, this result being associated with an inflationary bias, (6). This result is no longer fully verified if one considers the partisan version of electoral cycles with rational expectations.

Thus, if, as before, one considers the existence of two political parties, distinguishing themselves by their preferences in the instantaneous objective function (5), it is clear that, at any time in the mandate, with the exception of the first one, $\pi_{t}=\alpha \beta^{i}$ and $y=\bar{y}$. However, at the first moment of the mandate, $\pi_{t}^{e}=\mathrm{E}\left[\pi_{t} \mid \jmath_{t-1}\right]$ should be computed as

23. In this regard, it should be noted that the perspective of electoral cycles, assuming that popularity (or voting level) depends on the evolution of economic variables, actually represents a problem for the estimation of popularity or voting functions, by traditional econometric methods, taking into account the endogeneity of the variables implicit in it, such as, for example, assuming that the trajectories of the relevant electoral variables depend on the evolution of popularity throughout the mandate.

$$
\pi_{1}^{e}=p \pi_{1}^{L}+(1-p) \pi_{1}^{R}
$$

where $p$ represents the probability of electoral victory of the left-wing party (and $(1-p)$ the probability of victory of the right-wing party). Hence, as

$$
\pi_{1}^{R}<\pi_{1}^{e}<\pi_{1}^{L}
$$

the model shows that, at the beginning of a right (resp. left) wing government, output will be below (resp. above) its natural level. ${ }^{25}$ As soon as expectations and prices adjust, i.e. the so-called partisan effect disappears, output converges to its natural level, meaning that the level of economic activity, after adjustment, should be independent of the ruling party. ${ }^{26}$ As for the inflation rate, its level will always be higher during a leftist party's mandate, even after the level of economic activity converges to its natural level.

\section{The output persistence and the pat- tern of electoral cycles}

The aggregate supply curve (1) was - and, to some extent, still is - highly regarded in the literature as a representative model of how the economy works. $^{27}$

More recently, some authors have begun to recognize that indeed some (real) variables ex-

24. Obviously, if there is a third party, intermediate in the political spectrum, there may be a coincidence (also in the initial moment of the mandate) between the actual value and the expected value of the inflation rate, (Caleiro 1999).

25 . This (temporary) effect is usually associated with the fact that the election results are news. In terms of the evolution of the exchange rate, Ploeg (1989) considered this characteristic of the electoral results (Caleiro 2009a).

26. The empirical implications of models of party cycles with rational expectations may thus be summarized in that the real/state variable, $y$, assuming, as a result of the partisan effect, values temporarily above or below their natural value, during first part of the mandate, after which the values of $y$ return to their natural value, i.e. regardless of the type of party in power. In Caleiro (2005a) it was considered an empirical test of the relationship between economic growth and partisan cycles in Portugal.

27. As is well known, there are several ways to substantiate this type of economic model. For example, although the numbers appear to be exaggerated, Gärtner (1997a) argues that there are "sixty ways" to arrive at the aggregate supply curve. In fact, the "popularity" of this type of model may be due to the fact that it is simultaneously compatible, albeit for different reasons, with the neo-classical and neo-Keynesian views. 
hibit some persistence, i.e. inertia, over time. ${ }^{28}$ For example, with regard to the unemployment rate at European level, its persistence around high values was been theoretically justified by: (i) on the supply side of the labor market, by a (voluntary/involuntary) limited search for employment and (ii) on the demand side of the labor market, by an extended period of anti-inflationary restrictive policies.

Partly as a result of the dissatisfaction with the explanatory power of model (1), with respect to the results that are actually observed, some authors, more recently, have defended the existence of an autoregressive term in the model of real economic activity, in unemployment (Jonsson 1997; Lockwood 1997), or in output (Gärtner $1996,1997 \mathrm{~b}) .^{29}$

Thus, model (1) can / should be replaced by

$$
y_{t}=\bar{y}+\alpha\left(\pi_{t}-\pi_{t}^{e}\right)+\varphi y_{t-1},
$$

where $\varphi \in[0,1]$ measures the degree of output persistence. ${ }^{31}$

Clearly, a significant consequence of the consideration of persistence is that the optimization problem becomes intrinsically dynamic or intertemporal since, as a rule, the results of a given period become dependent on the one(s) verified in earlier periods.

In fact, when $\varphi \neq 0$ in (9), past errors of expectations influence the current level of output through the existence of (output) persistence.

Thus, the consideration of output persistence should substantially alter the results of the stylized model. One of the substantial changes has to do with the pattern of the electoral cycle. In this respect, Gärtner (1996, 1997b, 2000) has shown that persistence can change the pattern of

28. As Gärtner (1999) acknowledged, only around the turn of the century, authors began to pay attention to the fact that some real variables show some persistence over time, as a simple observation of reality would confirm (Caleiro 2012).

29. It is interesting to note from Lucas's original foundations $(1973,328)$ that it is possible to arrive at an expression with persistence in the output (Caleiro 2005a).

30. This way of introducing persistence, which results in the expression of type (9), is indeed the most common in the literature (Jonsson 1997; Lockwood 1997; Svensson 1997; Gärtner 2000).

31. Plainly, model (1) is a particular/specific case of the (more) general model (9), i.e. when $\varphi=0$. the political (business) cycle, i.e. that it can be electorally more favorable for the incumbent that the mandate begins with an expansion, ending with a contraction.

This result of the inversion of the political cycle is undoubtedly interesting, even for its consequences in terms of empirical studies of the detection of evidence of electoral cycles (Caleiro 2002). ${ }^{32}$

Notably, hat result depends on the specification of electorate preferences as well as on the specification for the expected inflation rate. Thus, we will look at the circumstances in which output persistence can reverse the pattern of the electoral cycle, when expected inflation is either adaptive or rational, and government preferences are quadratic in relation to inflation and output.

In formal terms, let us continue considering the voting function (2):

$$
V=\mu V_{1}+V_{2}
$$

but now assuming that

$$
V_{t}=-\frac{1}{2} \pi_{t}^{2}-\frac{1}{2} \beta\left(y_{t}-\tilde{y}\right)^{2},
$$

where output level is given by (9), whereas the expected rate of inflation is given by

$\pi_{t}^{e}=\gamma \pi_{t-1}+(1-\gamma) \pi_{t-1}^{e}$, according to the hypothesis of adaptive expectations, or by

$\pi_{t}^{e}=\mathrm{E}\left[\pi_{t} \mid \jmath_{t-1}\right]$, according to the hypothesis of rational expectations.

Considering first the case of rational expectations, i.e.

$$
\begin{aligned}
& \pi_{1}^{e}=\mathrm{E}\left[\pi_{1} \mid \mathcal{J}_{0}\right], \\
& \pi_{2}^{e}=\mathrm{E}\left[\pi_{2} \mid \mathcal{J}_{1}\right],
\end{aligned}
$$

it is easy to verify that the maximization of the voting level (10), subject to the supply curve (9) - where, to simplify, the natural output level

32. In fact, the mere finding of contractions followed by expansions over the term of office cannot be understood as revealing electoral behavior, unless the government, by ignorance, does not acknowledge the existence of persistence in the level of economic activity and thus use the stylized model presented above in the determination of its economic policy [see section $4]$. 
is normalized to zero, i.e. $\bar{y}=0-$, leads to the following inflation rates:

$$
\begin{gathered}
\pi_{1}=\frac{\alpha \beta}{\mu}\left(\left(\tilde{y}-\phi^{2} y_{0}\right) \phi+\left(\tilde{y}-\phi y_{0}\right) \mu\right), \\
\pi_{2} \\
=\alpha \beta\left(\tilde{y}-\phi^{2} y_{0}\right)
\end{gathered}
$$

which, in turn, result in output levels

$$
\begin{aligned}
& y_{1}=\phi y_{0}, \\
& y_{2}=\phi y_{1} .
\end{aligned}
$$

Consequently, the output levels will generally be above or below the natural level, according to the initial conditions.

If, in particular, there is no output persistence, i.e. $\varphi=0$, then output will be at its natural level. The absence of a cycle in the output, will also be verified in the economic policy, given that $\pi_{1}=\pi_{2}=\alpha \beta \tilde{y}$, which corresponds to the abovementioned inflation bias, (58).

The absence of cycle in the output will also occur in case of full persistence, i.e. $\varphi=1$, but in this case,

$$
\begin{aligned}
& \pi_{1}=\frac{1+\mu}{\mu} \alpha \beta\left(\tilde{y}-y_{0}\right), \\
& \pi_{2}=\alpha \beta\left(\tilde{y}-y_{0}\right),
\end{aligned}
$$

such meaning that

$$
\left|\pi_{1}\right|>\left|\pi_{2}\right|
$$

which results from the fact that the inflationary bias in the first period propagates its effects in the second period, this being propitious from the electoral point of view.

For intermediate values of persistence in the output, i.e. $0<\varphi<1$, both the typical political cycle pattern, i.e. $\pi_{2}>\pi_{1}$, and the atypical pattern, i.e. $\pi_{2}<\pi_{1}$, can be verified. In the case of adaptive expectations, i.e.

$$
\begin{aligned}
& \pi_{1}^{e}=\gamma \pi_{0}+(1-\gamma) \pi_{0}^{e}, \\
& \pi_{2}^{e}=\gamma \pi_{1}+(1-\gamma) \pi_{1}^{e},
\end{aligned}
$$

the maximization of the voting level (10), subject to the supply curve (9) - where, once again, to simply, the natural level of output is normalized to zero, i.e. $\bar{y}=0-$, leads to inflation rates, and corresponding output levels, which will evolve towards a steady-state cycle, i.e. a situation in which $\mathrm{y}_{2}=y_{0}, \pi_{2}=\pi_{0}$ and $\pi_{2}^{e}=\pi_{0}^{e}$. In this case, it is easy to show that

$$
\begin{aligned}
& y_{1}=\frac{\alpha}{(2-\gamma)(1+\phi)}\left(\pi_{1}-\pi_{2}\right), \\
& y_{2}=\frac{\alpha}{(2-\gamma)(1+\phi)}\left(\pi_{2}-\pi_{1}\right) .
\end{aligned}
$$

Following Caleiro (2009b), it is then possible to show that the sign of $\left(\pi_{2}-\pi_{1}\right)$ corresponds to the sign of $(y-\varphi)$, that is, what dictates the pattern observed in the political cycle is simply the relationship between the degree of persistence of expectations and the degree of output persistence. ${ }^{33}$ The atypical (resp. typical) pattern should be observed when $y<\varphi$ - see figure $1-($ resp. $y>\varphi)$ - see figure 2 .

Figure 1 - The atypical pattern

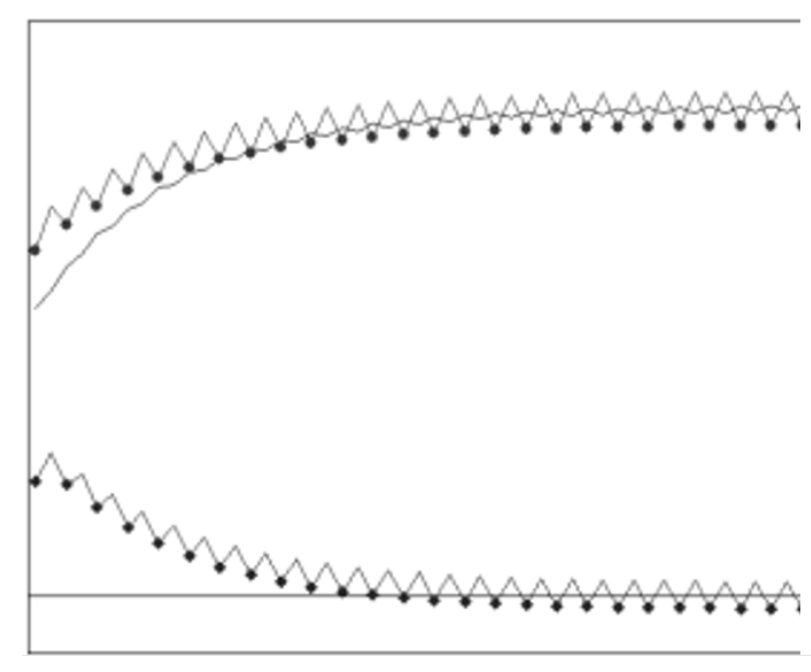

33. Caleiro (2009b) also shows that when expectations are rational, the case where there is no persistence in the output, i.e. the stylized model, is formally equivalent to the case $y=\varphi$, when expectations are adaptive (Minford and Peel 2002, 80-86). 
Figure 2 - The typical pattern

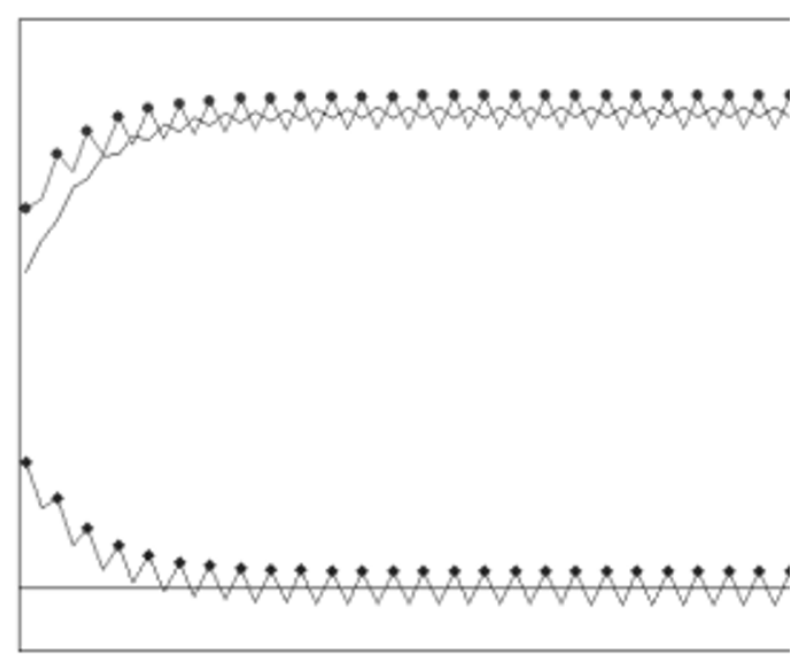

As far as the intuition behind this result is concerned, an observation by Gärtner (2000) is also valid for this case. In fact, while the expectation parameter, $y$, indicates how much more a percentage point of expected current inflation moves up the supply curve at the next moment, the persistence parameter in output, $\varphi$, measures the opposite effect, i.e., indicates how much this increase in current expected inflation moves down the supply curve of the next moment. If the effect of expectations dominates (resp. is dominated by) the effect of persistence, the typical (resp. atypical) pattern of political cycle is to be observed.

\section{Discussion}

An observation of reality, perhaps in terms of mere coincidence, seems to confirm that the pattern of the typical electoral cycle seems to be so ingrained that an electorally motivated government, ignorance, considers (a priori) that the best economic policy, for electoral purposes, is to implement contractions (more than socially desirable), at the beginning of the mandate, followed by expansions (more than socially desirable), at the end of the mandate.

In fact, as shown in section 3 , such behavior is not necessarily the one that provides the greatest electoral gains. Thus, government behavior of this kind seems to reveal that government can act in conditions of ignorance (of persistence), or in other words, use the stylized model, which is an incorrect model, in determining its policy measures (Chow 1977).
Following Caleiro (2014), it is possible to show that, in the case of a benevolent government, the maximization of

$$
W=W_{1}+\rho W_{2},
$$

where

$$
\begin{aligned}
& W_{t}=-\frac{1}{2} \pi_{t}^{2}+\beta y_{t}, \\
& y_{t}=\alpha\left(\pi_{t}-\pi_{t}^{e}\right)+\varphi y_{t-1}, \text { (correct model) or, }
\end{aligned}
$$
by ignorance, considered to be $\mathrm{y}_{t}=\alpha\left(\pi_{t}-\pi_{t}^{e}\right)$ (incorrect model) and

$$
\pi_{t}^{e}=\gamma \pi_{t-1}+(1-\gamma) \pi_{t-1}^{e}
$$

leads to the following differences between the use of the correct (c) and the incorrect (i) model, which are, for the inflation rates:

$$
\begin{array}{lc}
\pi_{1}^{i}-\pi_{1}^{c} & =-\lambda \alpha \phi \rho<0, \\
\pi_{2}^{i}-\pi_{2}^{c} & =0,
\end{array}
$$

whereas for output:

$$
\begin{aligned}
& y_{1}^{i}-y_{1}^{c}=-\lambda \phi \rho \alpha^{2}<0, \\
& y_{2}^{i}-y_{2}^{c}=-\lambda \phi \rho \alpha^{2}(\phi-\gamma) .
\end{aligned}
$$

that, in the steady-state cycle, are:

$$
\begin{aligned}
y_{1}^{i}-y_{1}^{c} & =-\frac{\lambda \rho \phi \alpha^{2}}{(1+\phi)(2-\gamma)}<0, \\
y_{2}^{i}-y_{2}^{c} & =\frac{\lambda \rho \phi \alpha^{2}}{(1+\phi)(2-\gamma)}>0 .
\end{aligned}
$$

In the case of an opportunistic government, when the voting function is given by:

$$
V=\mu\left(-\frac{1}{2} \pi_{1}^{2}+\beta y_{1}\right)+\left(-\frac{1}{2} \pi_{2}^{2}+\beta y_{2}\right) \text {, }
$$

and, again,

$\mathrm{y}_{t}=\alpha\left(\pi_{t}-\pi_{t}^{e}\right)+\varphi y_{t-1}$, (correct model) or, by ignorance, considered to be $\mathrm{y}_{t}=\alpha\left(\pi_{t}-\pi_{t}^{e}\right)$ (incorrect model) and 


$$
\pi_{t}^{e}=\gamma \pi_{t-1}+(1-\gamma) \pi_{t-1}^{e},
$$

it can be shown (Caleiro 2014) that the differences, for the inflation rates, between the use of the correct $(c)$ model and the incorrect $(i)$ model are given by:

$$
\begin{array}{rc}
\pi_{1}^{i}-\pi_{1}^{c} & =-\frac{\alpha \beta \phi}{\mu}<0, \\
\pi_{2}^{i}-\pi_{2}^{c} & =0,
\end{array}
$$

that is, a sub-utilization of the inflation rates, whereas, in terms of the output levels,

$$
\begin{aligned}
& \pi_{1}^{i}-\pi_{1}^{c}=-\frac{\alpha \beta \phi}{\mu}<0, \\
& \pi_{2}^{i}-\pi_{2}^{c}=0,
\end{aligned}
$$

that is, an under-utilization in the initial term of the mandate, while in the final period of the mandate, everything depends on the difference between the degree of persistence of expectations, $\gamma$, and the degree of output persistence, $\varphi$.

Still for this case, in the steady-state cycle situation:

$$
\begin{aligned}
y_{1}^{i}-y_{1}^{c} & =-\frac{\beta \phi \alpha^{2}}{\mu}<0 \\
y_{2}^{i}-y_{2}^{c} & =-\frac{\beta \phi \alpha^{2}}{\mu}(\phi-\gamma),
\end{aligned}
$$

In the long term, it can be said that the use of the incorrect model will lead to over-depression of the output at the beginning of the term and, at the end of it, to over-expansions. See figure 1 in Caleiro (2014).

\section{Conclusion}

The use of the wrong model by the government may be open to criticism based on the assumption that politicians will be aware of this. From this point of view, one hypothesis for future work is to admit that the existence of "shocks" - see, for example, Minford (1995) and/or Caleiro (2004b) - may lead to the perception that the incorrect model corresponds to the process generating the data, when this does not happen. Another possibility is to abandon the hypothesis of an opportunist government, in favor of a benevolent government, but presenting some restriction to its rationality (Sargent 1993) makes mistakes in classification of the trajectory observed for the economy, thus continuing to use the incorrect model. $^{34}$

\section{References}

[1] Agnew, John. 1996. "Mapping politics: how context counts in electoral geography." Political Geography 15: 129-146.

[2] Alesina, Alberto. 1987. "Macroeconomic Policy in a Twoparty System as a Repeated Game." The Quarterly Journal of Economics 102: 651-678.

[3] Alesina, Alberto, and Guido Tabellini. 1987. "Rules and Discretion with Noncoordinated Monetary and Fiscal Policies." Economic Inquiry 25(4): 619-630.

[4] Alesina, Alberto. 1992. "Macroeconomic Policy and Elections in OECD Democracies." Economics and Politics 4: 130 .

[5] Alesina, Alberto, and Nouriel Roubini. 1992. "Political Cycles in OECD Economies." Review of Economic Studies 59: 663-688.

[6] Alesina, Alberto, Gerald D. Cohen, and Nouriel Roubini. 1993. "Electoral Business Cycles in Industrial Democracies." European Journal of Political Economy 9: 1-24.

[7] Alesina, Alberto, and Roberto Perotti. 1994. "The Politics of Growth: A Survey of the Recent Literature." World Bank Economic Review 8: 351-372.

[8] Alesina, Alberto, and Dani Rodrik. 1994. "Distributive Politics and Economic Growth." Quarterly Journal of Economics 109: 465-490.

[9] Alesina, Alberto, Ozler Sule, Nouriel Roubini, and Phillip Swagel. 1996. "Political Instability and Economic Growth." Journal of Economic Growth 1(2): 189-211.

[10] Alesina, Alberto, Nouriel Roubini, and Gerald Cohen. 1997. Political Cycles and the Macroeconomy. Cambridge (MA): The MIT Press.

[11] Arrow, Kenneth. 1951. Social Choice and Individual Values. New Haven (CT): Yale University Press.

[12] Barro, Robert. 1996. "Democracy and Growth." Journal of Economic Growth 1(1): 1-27.

[13] Balke, Nathan. 1990. "The Rational Timing of Parliamentary Elections." Public Choice 65: 201-216.

[14] Balke, Nathan. 1991. "Partisanship Theory, Macroeconomic Outcomes, and Endogenous Elections." Southern Economic Journal 57(4): 920-935.

[15] Beck, Nathaniel, Kristian S. Gleditsch, and Kyle Beardsley. 2006. "Space is more than Geography: Using Spatial Econometrics in the Study of Political Economy." International Studies Quarterly 50: 27-44.

[16] Black, Duncan. 1948. "On the Rationale of Group Decision-making". Journal of Political Economy 56: 23-34.

[17] Black, Duncan. 1958. The Theory of Committees and Elections. Cambridge: Cambridge University Press.

[18] Buchanan, James M., and Gordon Tullock. 1962. The Calculus of Consent: Logical Foundations of Constitutional Democracy. Ann Harbor: The University of Michigan Press.

34. In any case, the research proposal of Caleiro (2018) may be a promising avenue for further analyzes. 
[19] Caleiro, António. 1999. "What if Third Parties Disappear? A rational partisan note." Estudos de Economia XIX(3): 349-356.

[20] Caleiro, António. 2000. "The Political Economics of Election Dates - An overview with some stylized models of economic policy". In Livro de Actas da 6. " Conferência do CEMAPRE: 557-575. Lisbon: Instituto Superior de Economia e Gestão.

[21] Caleiro, António. 2001. "Essays on Election Dates, Economic Policies and Voters." PhD Diss., European University Institute, Florence, Italy.

[22] Caleiro, António. 2002. "Acerca das Dificuldades na Detecção Empírica de Ciclos Eleitorais: Uma explicação através de alguns desenvolvimentos teóricos recentes." Economia e Sociologia 73: 5-22.

[23] Caleiro, António. 2005. "Crescimento Económico e Ciclos Partidários: Uma clarificação da relação existente". In Actas da conferência Políticas Públicas para o Desenvolvimento. Lisbon: Instituto Superior de Ciências do Trabalho e da Empresa.

[24] Caleiro, António. 2007a. "Uma Análise do Papel Económico das Eleições." Economia e Sociologia 84: 35-51.

[25] Caleiro, António. 2007b. "Acerca das consequências políticas do envelhecimento populacional: Uma visão económica." In Livro de Actas das VIII Jornadas do Departamento de Sociologia: 75-85. Évora: Departamento de Sociologia e Centro de Investigação em Sociologia e Antropologia 'Augusto da Silva'.

[26] Caleiro, António. 2009a. "The Political Economics Side of the J-Curve." The ICFAI Journal of Applied Economics VIII(3-4): 23-37.

[27] Caleiro, António. 2009b. "How upside down are political business cycles when there is output persistence." Research in Economics 63(1): 22-26.

[28] Caleiro, António. 2010a. "On the Synchronisation of Election Dates: The small vis-à-vis large economies case." Revista de Economía Mundial 24: 193-212.

[29] Caleiro, António. 2010b. "On the economic timing of elections: An optimal control case." Portuguese Journal of Quantitative Methods I(1): 53-71.

[30] Caleiro, António. 2012. "Output Persistence in Portugal." International Journal of Latest Trends in Finance and Economic Sciences 2(3): 206-210.

[31] Caleiro, António. 2014. "What if Output Persistence is Disregarded by an Opportunistic Incumbent?" International Journal of Latest Trends in Finance and Economic Sciences 4(4): 803-806.

[32] Caleiro, António, 2016. "On the Political Aspects of Unemployment: The Case of Election Results". In Unemployment: Economic, Political and Social Aspects, edited by Tabitha Fletcher: 97-126. New York: Nova Science Publishers.

[33] Caleiro, António. 2017. "Paz e Democracia - De que forma estão relacionadas?" Perspectivas, Journal of Political Science 17: 17-23.

[34] Caleiro, António. 2018. Should electoral cycles disappear? Research Proposal available at (http://doi.org/10.13140/ RG.2.2.27086.10561)

[35] Cargill, Thomas F., and Michael M. Hutchinson. 1991. "Political Business Cycles with Endogenous Election Timing: Evidence from Japan." The Review of Economics and Statistics 83(4): 733-739.

[36] Chappell, David, and David A. Peel. 1979. "On the Political Theory of the Business Cycle." Economics Letters 2: 327-332.

[37] Chow, Gregory. 1977. "Usefulness of imperfect models for the formulation of stabilization policies." Annals of Economic and Social Measurement 6(Spring): 175-188.

[38] Downs, Anthony. 1957. An Economic Theory of Democracy. New York: Harper.

[39] Ellis, Christopher. 1991. "Endogenous Voting in a Partisan Model with Rational Voters." Journal of Macroeconomics 13(2): 267-278.

[40] Ellis, Christopher J., and Mark A. Thomas. 1991. "Partisan Effects in Economies with Variable Electoral Terms." Journal of Money, Credit, and Banking 23(4): 728-741.

[41] Franzese, Robert J., and Jude C. Hays. 2007. "Spatial Econometric Models of Cross-Sectional Interdependence in Political Science Panel and Time-Series-Cross-Section Data." Political Analysis 15(2): 140-164.

[42] Gärtner, Manfred. 1994a. "Democracy, Elections, and Macroeconomic Policy: Two Decades of Progress." European Journal of Political Economy 10: 85-109.

[43] Gärtner, Manfred. 1994b. "The Quest for Political Cycles in OECD Economies." European Journal of Political Economy 10: 427-440.

[44] Gärtner, Manfred. 1996. "Political Business Cycles When Real Activity is Persistent." Journal of Macroeconomics 18(4): 679-692.

[45] Gärtner, Manfred. 1997a. A Primer in European Macroeconomics. Prentice Hall Europe.

[46] Gärtner, Manfred. 1997b. "Time-consistent monetary policy under output persistence." Public Choice 92: 429-437.

[47] Gärtner, Manfred. 1999. "The Election Cycle in the Inflation Bias: Evidence from the G-7 countries." European Journal of Political Economy 15: 705-725.

[48] Gärtner, Manfred. 2000. "Political Macroeconomics: A Survey of Recent Developments." Journal of Economic Surveys 14(5): 527-561.

[49] Goyal, Sanjeev, and Klaas Staal. 2004. "The political economy of regionalism." European Economic Review 48: 563-593.

[50] Heckelman, Jac. 2002. "Variable Rational Partisan Business Cycles: theory and some evidence." Canadian Journal of Economics 35(3): 568-585.

[51] Hibbs, Douglas. 1977. "Political Parties and Macroeconomic Policy." American Political Science Review 71: 14671487.

[52] Ito, Takatoshi. 1990. "The Timing of Elections and the Political Business Cycles in Japan." Journal of Asian Economics 1(1): 135-146.

[53] Jonsson, Gunnar. 1997. "Monetary Politics and Unemployment Persistence." Journal of Monetary Economics 39(2): 303-325.

[54] Kalecki, Michal. 1943. "Political Aspects of Full Employment." Political Quarterly 14(4): 322-331.

[55] Kayser, Mark Andreas. 2005. "Who surfs, who manipulates? The determinants of opportunistic election timing and electorally motivated economic intervention." American Political Science Review 99: 17-28.

[56] Keppo, Jussi, Lones Smith, and Dimitry Davydov. 2008. "Optimal Electoral Timing: Exercise Wisely and You May Live Longer." Review of Economic Studies 75(2): 597-628.

[57] Kramer, Gerald. 1983. "The ecological fallacy revisited: aggregate- versus individual-level findings on economics and elections, and sociotropic voting." The American Political Science Review 77(1): 92-107.

[58] Lächler, Ulrich. 1982. "On political business cycles with endogenous election dates." Journal of Public Economics 17: 111-117.

[59] Lewis-Beck, Michael S., and Martin Paldam. 2000. "Eco- 
nomic voting: an introduction." Electoral Studies 19: 113121.

[60] Lewis-Beck, Michael S., and Mary Stegmaier. 2013. "The VP-function revisited: a survey of the literature on vote and popularity functions after over 40 years." Public Choice 157(3-4): 367-385.

[61] Ljungqvist, Lars, and Thomas J. Sargent. 2004. Recursive Macroeconomic Theory. Cambridge (MA): The MIT Press.

[62] Lockwood, Ben. 1997. "State-Contingent Inflation Contracts and Unemployment Persistence." Journal of Money, Credit, and Banking 29(3): 286-299.

[63] Lohmann, Susanne. 1993. "Electoral Cycles and International Policy Cooperation." European Economic Review 37(7): 1373-1391.

[64] Lucas, Robert. 1973. "Some International Evidence on Output-Inflation Tradeoffs." American Economic Review 63(3): 326-334.

[65] Mankiw, N. Gregory. 2008. Principles of Microeconomics. Mason (OH): South-Western Cengage Learning.

[66] Minford, Patrick, and David Peel. 1982. "The Political Theory of the Business Cycle." European Economic Review 17: 253-270.

[67] Minford, Patrick. 1990. "Ulysses and the Sirens: A Political Model of Credibility in an Open Economy". In Private Behaviour and Government Policy in Interdependent Economies, edited by Anthony S. Courakis and Mark P. Taylor: 337-355. Oxford: Oxford University Press.

[68] Minford, Patrick. 1995. "Time-Inconsistency, Democracy, and Optimal Contingent Rules." Oxford Economic Papers 47(2): 195-210.

[69] Nannestad, Peter, and Martin Paldam. 1994. "The VPFunction: A survey of the literature on vote and popularity function after 25 years." Public Choice 79: 213-245.

[70] Nordhaus, William. 1975. "The Political Business Cycle." The Review of Economic Studies 42(2): 169-190.

[71] O'Loughlin, John. 2003. "Spatial analysis in political geography". In A companion to political geography, edited by John A. Agnew, Katharyne Mitchell and Gerard Toal: 3046. Oxford: Basil Blackwell.

[72] Olson, Mancur. 1965. The Logic of Collective Action. Harvard: Harvard University Press.

[73] Persson, Tortsten, and Guido Tabellini. 1990. Macroeconomic Policy, Credibility and Politics. London: Harwood Academic Publishers.

[74] Persson, Tortsten, and Guido Tabellini. 1999. "Political Economics and Macroeconomic Policy". In Handbook of Macroeconomics, edited by John B. Taylor and Michael Woodford: 1397-1482. Amsterdam: Elsevier Science.

[75] Persson, Tortsten, and Guido Tabellini. 2000. Political Economics: Explaining Economic Policy. Cambridge (MA): The MIT Press.

[76] Persson, Tortsten, and Guido Tabellini. 2003. The Economic Effects of Constitutions. Cambridge (MA): The MIT Press.

[77] Persson, Tortsten, and Guido Tabellini. 2006. "Democracy and Development: The Devil in the Details." American Economic Review 96(2): 319-324.

[78] Ploeg, Frederick van der. 1989. "The Political Economy of Overvaluation." The Economic Journal 99: 850-855.

[79] Rogoff, Kenneth, and Anne Siebert. 1988. "Elections and macroeconomic policy cycles." Review of Economic Studies 55: 1-16.

[80] Sapir, Andre, and Khalid Sekkat. 1999. "Optimum Electoral Areas: Should Europe adopt a single election day?" European Economic Review 43(8): 1595-1619.
[81] Sargent, Thomas. 1987. Macroeconomic Theory. San Diego: Academic Press.

[82] Sargent, Thomas. 1993. Bounded rationality in macroeconomics: The Arne Ryde memorial lectures. Oxford: Clarendon Press.

[83] Smith, Alastair. 1996. "Endogenous election timing in majoritarian parliamentary systems." Economics and Politics 8: 85-110.

[84] Svensson, Lars. 1997. "Optimal Inflation Targets "Conservative' Central Banks, and Linear Inflation Contracts." American Economic Review 87(1): 98-114.

[85] Taylor, John. 1980. "Aggregate Dynamics and Staggered Contracts." Journal of Political Economy 88(1): 1-23.

[86] Veiga, Francisco José, and Linda Gonçalves Veiga. 2004. "The Determinants of Vote Intentions in Portugal". Public Choice 118(3-4): 341-364.

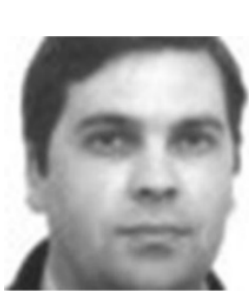

António Bento Caleiro holds a degree in Economics from the University of Évora, a Master's degree in Mathematics Applied to Economics and Management from the Higher Institute of Economics and Management (Lisbon) and a Ph.D. in Economics from the European University Institute (Florence). He is currently an Assistant Professor with Aggregation at the University of Évora. His research interests are (evidently) of a multidisciplinary nature, as the present work illustrates. 